\title{
情緒障害児への環境療法の展開にみる小舎型施設空間の意味 MEANINGS OF SPACE OF COTTAGE-TYPE RESIDENTIAL CENTER IN MILIEU THERAPY FOR EMOTIONALLY DISTURBED CHILDREN
}

\author{
石垣 文*, 菅野 實**, 小野田 泰明***, 坂 口大洋**** \\ Aya ISHIGAKI, Minoru KANNO, Yasuaki ONODA \\ and Taiyo SAKAGUCHI
}

\begin{abstract}
The number of emotionally disturbed children in Japan has been increasing recently; however, only few attempts with an aim at improving children' $s$ living space have been made at treatment centers. We conducted some field surveys on the cottagetype residential center to examine the relationship among space, communication, and the effectiveness of therapy. In addition, to clarify conditions of 'treatment for children with emotional disturbances, the children' $s$ daily life with milieu therapy was observed. The main results are as follows.

1. In the milieu therapy, it consisted of two dimensions, "counseling" and "daily life", and they were strongly associated.

2. On their daily life, members were working together to establish appropriate relationships. Then, based on their relationships, the staff conducted counseling using spacious elements in the better settings.

3. It can be said that the characteristics such as floor space, the number of children, and the organization of the space, contributed to a better condition for the milieu therapy.
\end{abstract}

Keymords: emotional disturbance, residential treatment center for emotionally disturbed children, milieu therapy, cottage-type residential center

情緒障害、情緒障害児短期治療施設、環境療法、小舎型施設

\section{1. 研究の背景}

育児不安、虐待問題やいじめ、不登校やひきこもり、不可解な荒れ など親子をとりまく問題は深刻化し、それに伴い「情緒障害児」とい われる子どもの数が急増している。情緒障害とは「家庭内の人間関係 とくに親子関係の障害により正常な感情生活に支障をきたし、不安定 な状態が持続している状態」文りをいうが、背景には溺愛、過干涉か ら虐待まで様々な家庭の事情がある。こうした情緒的な不安定状態 は、彼らの正常な社会対応の発達を妨げ、問題行動によって周囲を混 乱に陥れることも多い。

日本における社会的貧困を要因としない非行や不登校の問題は、都 市化が急激に進行し、大きな生活環境変化が起った昭和 30 年代に顕 在化しているが、これらの情緒発達のつまづきを心理失調と捉え、対 応するメンタルケアの拋点として、1961年児童福祉法により制度化さ れたのが『情緒障害児短期治療施設 (以下情短施設と略す)』社1)であ る。この施設はセラピストが常駐して心理学的治療がなされるととも に短期の「退所」を目標とする点で他の児童福祉施設とは性格を異に しているが、近年になって地域における子どもたちのメンタルケアの 中核施設としての期待から、全国的な整備が求められつつある維2。

児童虐待の問題は我が国では 1990 年頃から顕在化しており、情短 施設でも被虐待児が在籍児童の6割程度を占めるようになっているが
文2)、この変化は情短施設での療育も変容させている。情短施設の心 理治療は通常、構造化された面接神3)(カウンセリング）と構造化され ていない面接（環境療法䓜4)）に分けられ、施設の治療方針によりそ の両者、または一方が活用されているが、養護施設や病院の精神科領 域における近年の治療研究の展開を散見すると、被虐待児にはカウン セリングやセラピーといった時間的・空間的制約のもとに治療を行う 方法より、日常的な環境内で継続的に展開される環境療法の方が効果 的であるとする報告も多い文.4.5)。そうした流れを受け、情短施設で も被虐待児のみならず広く情緒障害児一般に向けられる治療法として 環境療法が受け入れられつつある文6)。

さらに背景となる養護諭の変化もみのがせない。これまで、「施設 養護」と「家庭養護（里親制度等）」の二極化の傾向にあった児童福 祉論であるが、近年ではグループホームなどを介して相互依存的 ネットワークを形成し、その網の目の中で施設を再定義していこう とする中間的な流れが出ている刘。一方、入所する子どもの多様化・ 複雑化によって「集団づくり」が困難になるなど、施設養護の現場 も新しい問題を抱えるようになっている。浅倉文》らは先述の潮流の 変化をひきながら、施設の生活集団を小規模化することで子どもと 職員の継続的・情緒的な人間関係を保証する「家庭的小集団羑護」の 有効性を提示している。

\footnotetext{
* 東北大学大学院工学研究科 大学院生・工修

** 東北大学大学院工学研究科 教授. 工博

**** 東北大学大学院工学研究科 助教授 ·博士 (工学)

**** 東北大学大学院工学研究科 助手.工修
}

Graduate Student, Graduate School, University of Tohoku, M. Eng. Prof., Graduate School, University of Tohoku, Dr. Eng.

Assoc. Prof., Graduate School, University of Tohoku, Dr. Eng. Research Assoc., Graduate School, University of Tohoku, M. Eng. 
こうした状況にありながら我が国の養護施設は、管理体制・施設基 準といった理由から大舎制養護睡5)が主流を占めている(津崎文8)）。 舎型施設は、その重要性は認められながらも勤務体制等の制約からほ とんど実現しておらず、2003年 3 月現在、小舎型情短施設は 21 施設 中1施設に留まっているのである。そうした制約もあり、建築分野に おける小舎型施設の研究は散見される文9.10)にすぎない。

\section{2. 研究の目的と方法}

\section{2-1 研究の目的}

本研究では複雑化する社会や過程をサポートする重要な拠点となり うる情短施設の役割に着目し、今後あるべき整備や運用の方法を見出 そうとするものである。具体的には全国唯一の小舎型施設で、かつ環 境療法を行っているKホーム肺6) (図 1) を対象とし、そこでの環境療 法の展開を子どもの言動や施設空間などを含めて記述し、情緒障害児 の療育のために必要な要件を明らかにしていく。

\section{2-2 研究の方法}

本研究ではまず、既往の研究より環境療法の治療モデルを構築す る。次いで環境療法の展開を「日常生活」場面、「話し合い」場面の 2つの側面から記述し、またその結果生じる子どもの適応過程を捉 え、環境療法と空間の関係を記述する。

情緒障害児に対する環境療法の大枠は次のように理解することが 出来る (図 2) 得8)。人の心の機能が健常な場合、人は外界からの圧力 や進入、内界からの表出をコントロールしている状態にある。こうし た心の機能は、子どもの場合には未成熟であり、養育者による適切な 保護を受けることが必要である。一方、情緒障害児の心はそのような 保護が不十分である等の理由で非常に脆弱な状態にありそれをうまく コントロールできず、問題行動としての表れが顕著になる。心理的援 助はこの失われた心の機能の修復と心の自立性の獲得に向けられる。 本論ではこの援助が環境療法において「日常生活」場面とその中に埋 め込まれた「話し合い場面によって行われているとして整理した。

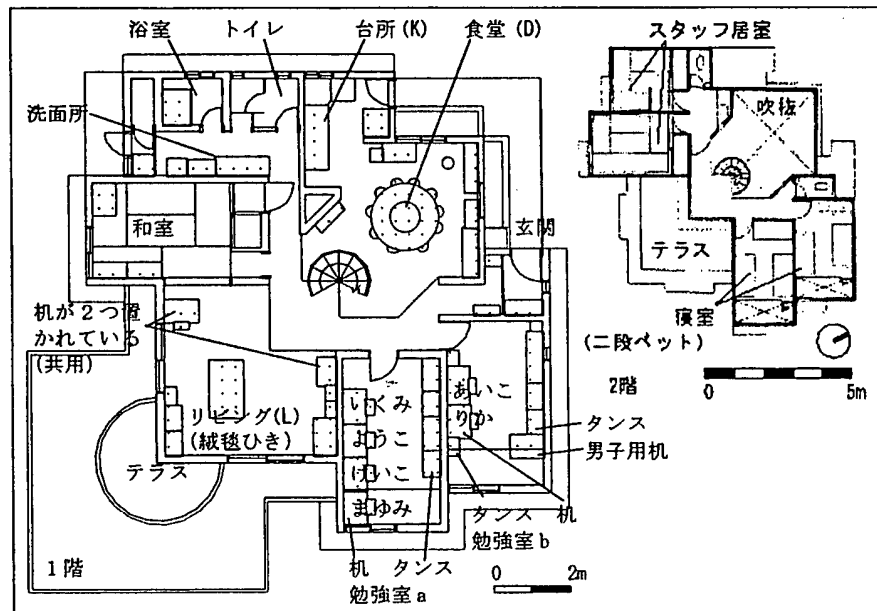

※勉強室には各自の机とタンスがあるが宿題などは食堂で行うことになっている。和室 は収納空問として使われている。勉蚛室中の名前は各自の机を示才。小学生男子は尃用

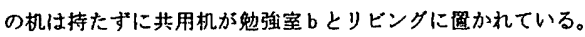
所在地 : 宮城県仙台市
敦工年
$: 1971 \sim 78$ 年
延床面稹 : :コテージ (5 棟) $982 \mathrm{~m}^{2}$. 㙩育センター $404 \mathrm{~m}^{2}$
構造 : コテージ RCB 造 2 階建、療育センター RC 造 2 階建

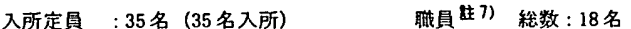
通学校 : 地域の公立小・中学校、高校は各自の進学校

\section{図 1. 調査対象施設の概要}

「日常生活」場面では、子どもの働きかけはスタッフや他の子どもに 受容され、その反応を受け取る (フィードバック)ことになる。この 受容・フィードバックの経験の蓄積により子どもは外界から保護さ れ、自他境界が強化されまた表出が援助されるようになる。「話し合 い場面では問題行動を起こした子どもはスタッフの代弁を借りて自 分の考えや感情を言語化し、整理し理解することになる。この「日常 生活」及び「話し合い場面を日々繰り返すことで子どもの心は安定 し、また新しい行動を知り、実行することで問題行動を改善していく のである晴9)。

調査では、実際に情緒障害児が生活する小舎型施設に滞在し、「日 常生活」場面と「話し合い」場面における典型的な関係構築の把握を めざした。そのため研究態度として、近年社会学や認知科学などで注 目され始めているエスノメソドロジー腈11,12) を採用している。それ は、情短施設は子どもの心理的発達のサポートをコミュニケーション によって実現しようとしており、そういった位相を捉えるにふさわし いと判断したためである。

データの再構築は次の $4 つ の$ 層で行った。まず、Kホームにおける 「日常生活」場面の展開を示し、LDKを中心にして子どもが人間関係を 構築する様を明らかにした。次いで「日常生活」場面の文脈の中に織 り込まれている具体的な「話し合い」場面を抽出し、その特徵を示し た。最後に両者を通じて表れる子どもの適応過程を記した。

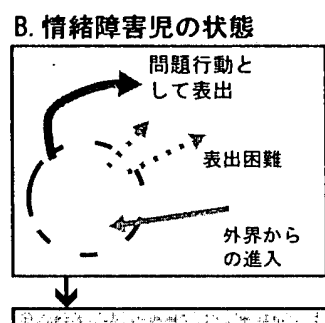

\section{A. 心の機能が健常な状態}
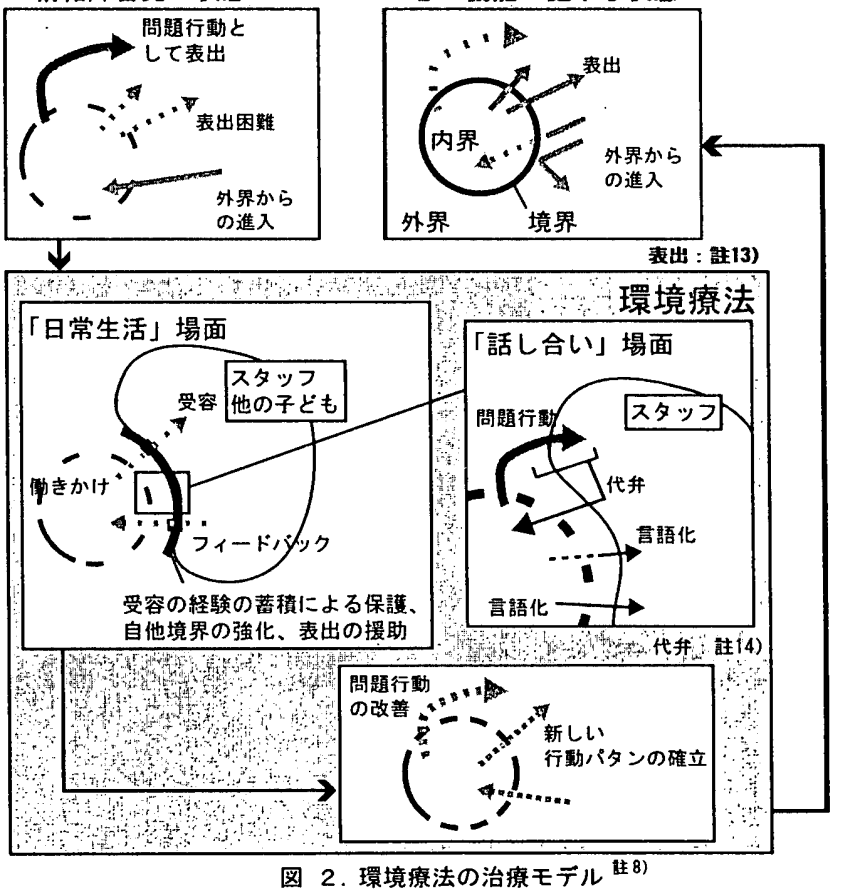

表1. 調査対象コテーシの入所児童 2002 年 10 月現在

\begin{tabular}{|c|c|c|c|c|c|c|}
\hline 名前 & 学年 & 入所日 & $\begin{array}{l}\text { 在所期間 } \\
(力 月)\end{array}$ & 男 & 女 & 主咴 \\
\hline Lよj & 小1 & $2002 / 5 / 1$ & 6 & O & & 母からの䖒特 \\
\hline なおと & 小2 & $2002 / 7 / 4$ & 4 & 0 & & 處待 (一時保藂委喆) \\
\hline Uでき & 小3 & $2000 / 8 / 30$ & 26 & $\mathrm{O}$ & & 虎持 \\
\hline あいこ & 小5 & $1998 / 6 / 22$ & 53 & & 0 & 繁母の拒否感（兄弟で入所） \\
\hline ようこ & 小5 & $2002 / 9 / 26$ & 1 & & 0 & 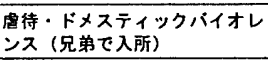 \\
\hline リか & 中1 & $1999 / 8 / 23$ & 39 & & o & $\begin{array}{l}\text { 不登校・舟が亡くなるため（当 } \\
\text { 時）心の整理 }\end{array}$ \\
\hline まゆみ & 中 2 & $1998 / 4 / 27$ & 55 & & 0 & 䖒待 \\
\hline いくみ & 中 3 & $2002 / 4$ & 7 & & 0 & 虚待 \\
\hline Hいこ & 高 3 & $1997 / 2$ & 69 & & O & 盧待 \\
\hline
\end{tabular}




\section{$2-3$ 調査の概要}

对象施設であるKホーム（図1）は5つのコテージを有するが、主 に職員勤務体制の関係から調查時に実際に使用されていたのは、4つ のコテージであった。生活場面への参与調査（行動の記述、会話録音） は、そのうち運営者から調査を許された「まつのみ」と呼ばれるコ テージを対象とした。実際には 2002 年 10 月から 12 月までの延べ 21 日間、每日 16 時半から 17 時半までの 1 時間子ども達と生活をともに 過ごして行った訳15)。調査員が調查対象者に強い影響を与えないよう にするため、調查の 3 ケ月前から訪問を絽り返しスタッフや子どもと 過ごした。また調査時間の前には子どもと遊ぶこと、調査中室内では 積極的な役割を持たず観察に徹することを心がけた。データ収集には 5 分間隔のマッピング(調查員は主に室内を見渡せる食堂に座り入所 児童の居場所、行為内容、動線等を平面上にプロット)、スケッチ、会 話の録音を行った辣16)。朝の職員連絡会への参加及びスタッフへのヒ アリング柱17) もあわせて、フィールドノーツを記録した文11。

\section{Kホームにおける生活像}

Kホームでは、就寝時以外を過ごす 1 階が 1 日の生活の中心の場と なる。食事及び勉強は食堂で行われ、自由時間の遊び・読書・語らい などの行為は食堂、リビング、勉強室で展開されており子どもの滞在 場所及び動線も同室内に分布していることが観察された(行為例の一 部は図 4,5,7,8,9参照)。スタッフは掃除・洗濯また外部との連絡な どで室内外を動き回るが、食事作りや書類作成などの場として台所、 食堂を活動の拠点としている。食堂からは台所、リビング、勉強室や 階段、2 階の郎下など室内及び玄関ポーチを見渡すことができる空間 のつくりとなっている。

滞在場所の記録 (図3) からは多くの子どもは勉強室にはあまり滞 在せず、行為を共有するしないに関わらずスタッフや他の子どもが滞 在するLDKで過ごしていることが分かる。また中高生（いくみ、けい こ）は小学生がリビングで過ごす間は台所、食堂で手伝いをするか勉 強室で過ごす傾向にあることが分かる教19)。まゆみは唯一勉強室（勉 強室a）にこもるタイプであっ たがドアは常に開放され、ス タッフからは見通しのきく状 態であった。観察よりおおよ そ子ども達は台所、食卓をス タッフとの関わりを積極的に 持つ空間、絨掞引きのリビン グを子ども同士で関わる空間、 そして勉強室をひとりのため の空間として使い分けている

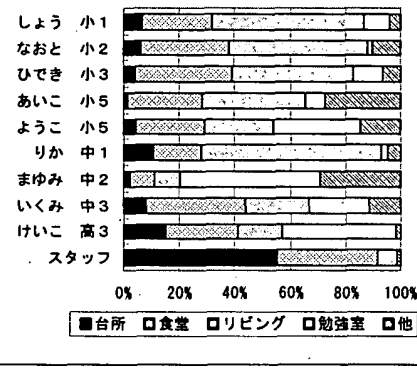

図3.3ヶ月の滞在場所の構成比 ${ }^{\text {妾 } 18)}$ ことが分かった。

\section{4.「日常生活」場面における関係構築}

関係構築はその相手によって、スタッフ、同年代、年代の異なる子 どもの三種類に区分できる。ここでは、前二者を 4-1 で、後者を 4-2 で取り上げる。

4-1スタッフへの働きかけとフィードバック

「日常生活」場面において子どもはスタッフへの働きかけ踥20)を きっかけとして受容の経験を蓄積していく。こうした経験はスタッフ と子どもの関係構築だけでは無く、子ども同士の関係にもフィード
バックしていく。5月入所当初、人と言葉を交わすことが十分にでき なかったしょうが、スタッフとの関わりを起点としながら同年代の子 ども同士での関係構築を行ったのはその典型例である。以下に示すの は夕食づくりの手伝いを通じてスタッフとの関わりを持ち、居場所を 獲得しょうとするしょうの働きかけの場面である（図4)。

$17: 2311 / 10 / 2002$. Sun

[布团を敖き、2階から降りてきたし上之は夕食の手伝いをするなお抢に興味を示した。]

1しょう：何してるの?何やってるの? おらもやりたい。

2森： 自分のこと全部終わってからだよ。

3しょう：おらやったよ。

4 森：もよやってきたの?

う: :ん?早いよ。

5しょう：床に全部なければいの?

6森： 床、床にはもちろん、きちっと整理して。

[中略]

11しょう：森さ：ん、もうちょっとで終わる。

12 森

(.)

13ひでき：おれも整理しょ：：

14 森：お：：、してくれ。うれしいな。

勉強室bから叫んだしょうの声 (11) はリビングのひできにも聞こ えた。ひできは立ち上がり、片づけをするために勉強室bに向かった。 一方なおとは、片づけが全て終わったと手伝いをせがむしょうに対し て競争心（「布団も（敷いたの）？」(23))をみせている。

17:30 11/10/2002. Sun

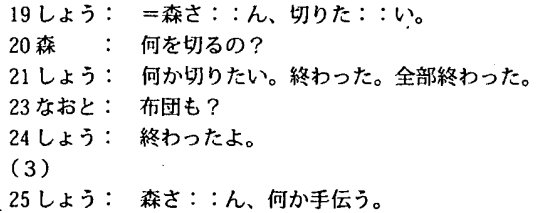

しょうは入所半年後(11月)には徐々に人との会話ができるように なったが、まだ子ども同士で遊ぶことはできず、子ども達の中に居場 所を見出せないでいた。この頃、男子の間で競うように夕食の手伝い が行われていたが、しょうはここに示したような関わりを何度か繰り 返すことを通じてスタッフとの新たな関わり方を学んでいく。しょう のこの行動は「台所での夕食づくり」という空間とプログラムが一体 化した明解な環境を手がかりとした居場所獲得のための働きかけであ り、しょうの働きかけをスタッフが受け止めてくれるという人間関係 の構築とセットになった行動でもある。またこの場面では、なおと、 ひできの関与が同時に観察されており、スタッブとの関係を軸に同年

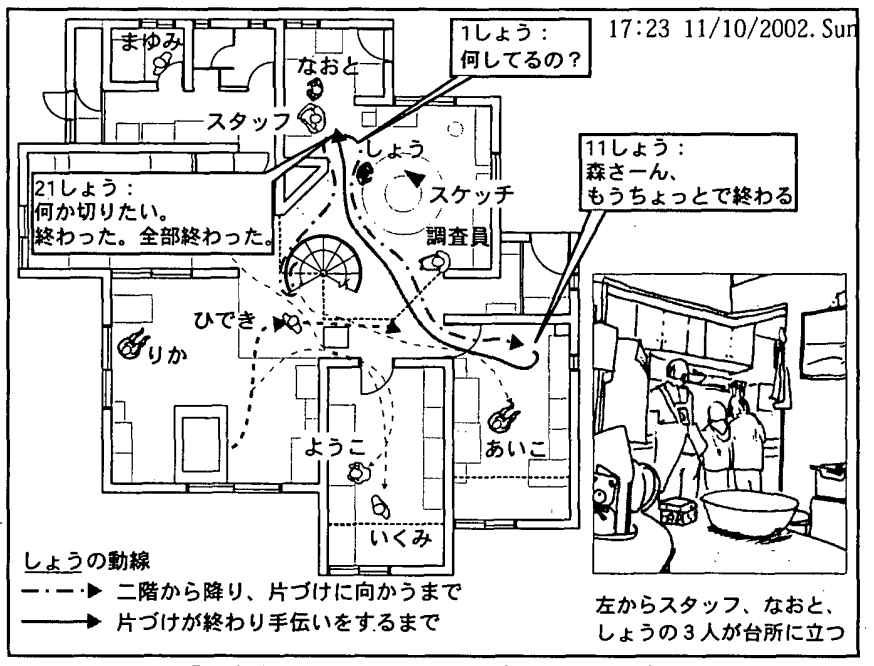

図4.「日常生活」場面における環境療法の展開事例（1） 


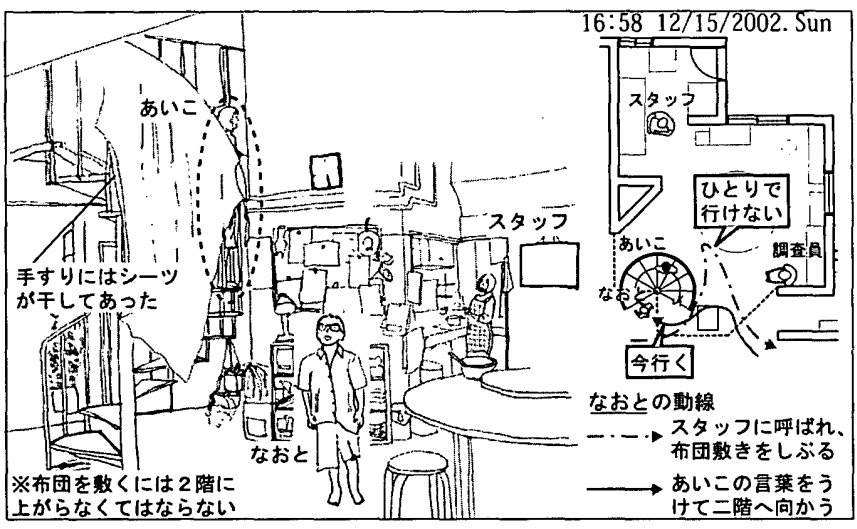

图5.「日常生活」場面における㻴境療法の展開事例 (2)

代の子ども間での関保が同時に形成されているとも見ることができ る。また図4に見る様に、行為の間しょうは一所に留まらず、階段や テーブルに沿って動きながらスタッフへの働きかけを行っていたが、 他の場面でも同样に子どもが動きながら行う㗢きかけが多く観察され ており (図9参照)、広がりや回遊性といった空間の特質が働きかけ に関係していることも見て取れる。

\section{4-2 空間の活用と生活集団形成}

室内を移動するスタッフも夕方時過ぎから夕食片付けまではほほ 台所で過ごすため、居場所が明確となる。それに応じて子ども達も食 堂、台所で思い思いにスタッフへの働きかけを行う。そうした働きか けを有効に行うために子ども達が空間の特性を活用しているケースも いくつか観察された。また、子ども達が集まっている分、そこでの㗢 きかけは生活集団の関係性にも影響を与える。以下に示すのは、西い こが空間を上手く活用し、生活集団形成(ここでは年長者から年少者 への㗢きかけ)に寄与したケースである。

$16: 5812 / 15 / 2002$. Sun
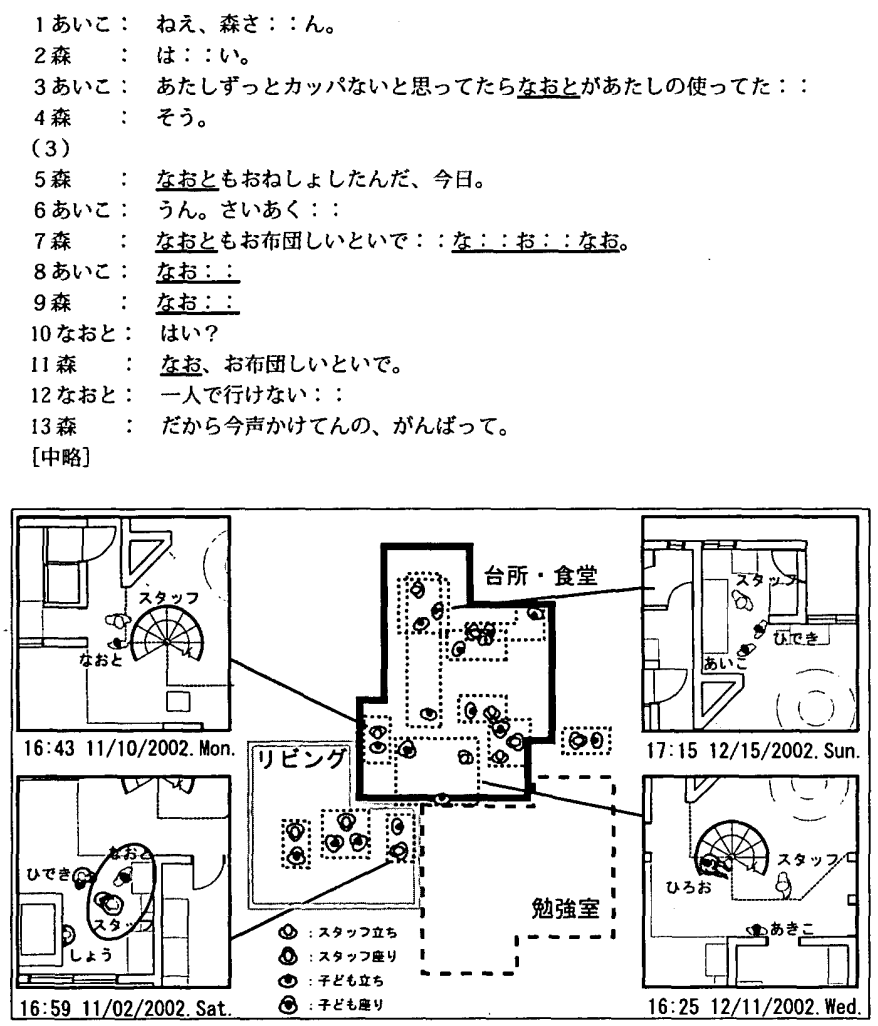

図6、「話し合い」場面の空間構成
30あいこ：今ならあっこも手伝ってあげる。

(3)

31 あいこ：なおと?

32 なおと：は: :い?

33あいこ：今らなあいこも手伝って/あげる

34 㷊：／お：：すご：い、あいこありがとう。

35 あいこ：森さんの代わりに手伝ってあげるよ。

36 森： ありがとう。

37なおと：おほほほほほ。

(6)

38あいこ：なおと：森さ：：ん、今ならあたしも手伝ってあけるよ。

[五いこ、涴室に入っていきながら叫ぶ]

39 なおと：うん、今行く：：

40 森：がんばれなおと。

[なおと、歌をうたいながら二階に上がっていく］

スタッフがなおとへ声をかけたのは西いこの発言（3）からなおと のおねしょを思い出した（5）ためである。ここからスタッフ、子ど もの両者は指導する側、される側という関係だけではなくスタッフの 状況把握を子どもが助けるといった相補的な関係を築いていることが

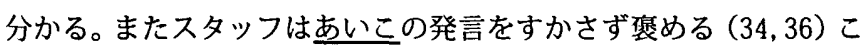
とでフィードバックを行っているが、この時のあいこの発言 (33, 35, 38) はスタッフの日頃の口癖（「今なら私が手伝ってあげる よ」）と同じであった。市いこがスタッフを自分の行動モデルとして いることが読みとれる。この機会はあらかじめ意図したというより、 日常的なやりとりから偶発的に発生したものであった。一方、あいこ は意図的に階段のこの位置（図5）から話し掛けているが、守られな がらも見渡せるこの空間の特性を通し、スタッフとなおとの両者に対 する働きかけを成立させている。また、この働きかけで、あいこはな 抢とに対して年長者としての関係性も強化しているが、これは生活集 団の基礎を構築している場面であると見ることもできる。

\section{5.「話し合い」場面の特衜}

5-1 空間との関係

「話し合い」場面は「日常生活」場面と同じ空間において行われて いるが、問題行動を解消する目的で展開され、観察上も「日常生活 場面」とほぼ区分可能である辣21)。「話し合い」は、問題行動が起きた 時、即座にその場で始められるが文12)、実際に観察された大半は台所、 食堂、リビングにおいてであった。一方、それぞれの空間構成やス タッフと子どもの距離は異なっている (図6、表2)。問題行動の指摘 は台所、食堂、リビングといったコミュニケーションが錯綜する空間 でなされることが多いが、「話し合い」が展開される場所は状況に応

表2、「話し合い場面におけるスタッフと子どもの距離関係

\begin{tabular}{|c|c|c|c|}
\hline 距離 & 2 人のケース & 3 人のケース & コメント \\
\hline 800 & 00 & & \multirow{2}{*}{$\begin{array}{l}\text { 「2人密接」 } \\
2 \text { 人の距離は密接するほどに近い。 } \\
700 \mathrm{~m} \text { というのは小学生中学年が手を } \\
\text { 伸ばして届く笧囲である。2人の関係 } \\
\text { は向き合う、90度で向き合うなどがあ } \\
\text { る。 }\end{array}$} \\
\hline 1200 & (2)0 & & \\
\hline 1600 & $Q$ & & $\begin{array}{l}\text { 「人密接」 } \\
\text { 3人の位置関係はほぼ等距離に保たれ } \\
\text { る。小学校低・中学年の子どもの話し } \\
\text { 合いに見られる。 }\end{array}$ \\
\hline 2400 & & $\varnothing$ & $\begin{array}{l}\text { 「ろ人離散」 } \\
\text { 3人の位㯰関係は、ほほ等距離に保た } \\
\text { れる。小学高学年の話し合いでみられ } \\
\text { た。 }\end{array}$ \\
\hline 2800 & & & $\begin{array}{l}\text { 「2人離散」 } \\
\text { 極端に距離をとる場面ではその子ども } \\
\text { が他にすべき事があり、話し合いの俊 } \\
\text { 先蕦位が低いときにみられる。 }\end{array}$ \\
\hline [単䅧mm] & & & $\begin{array}{ll}\text { @ スタッフ立ち } & \text { ○子ども立ち } \\
\text { @ スタッフ座り } & \text { ○子ども座り }\end{array}$ \\
\hline
\end{tabular}


じて随時設定されている。しかしその設定時には、壁や階段の手す り、家具といった空間構成要素や立つ、座るといった姿勢などが意識 されていることが、スタッフに対するヒアリングから裹づけられてい る船17)。

\section{5-2「日常生活」場面における「話し合い」場面}

「話し合い」場面の構成としては、「導入」「事実確認」「対応袙22)」 「終結」の 4 過程から構成される。本節では、最も頻発する問題行動 の例である嘘についての「話し合い」場面を先の 4 過程が確認しやす いなおとのケースを（図 7) を中心に説明する。

この日の昼スタッフに嘘をついたなおとは、「もう家に帰ってこな くていい」と言われていた。門限の17時に、スタッフは夕食の支度 をしつつ食卓であいこに宿題を教えていた。

「導入」では、スタッフがなおとの様子を同いつつ徐々に2人の距 離を縮め、「話し合い」を始めた。

「事実確認」ではなおとの意見を確認した。この時スタッフはしゃ がみ込みなおとと目線を会わせて向き合い、体が触れるほど近い距 離をとった。これは彼に話を伝えるために必要な距離であり、他の スタッフとなおとの話し合いからも共通に観察されたものである。 尚、あいこはスタッフに話しかけ、自分に注意を向けようとしたが、 スタッフはこれを無視してなおとの「話し合い」の場を維持した。

「対応」では問題の原因と解決方法が示される。それを一人で導く ことのできないなおとにスタッフは代弁腈14)することで伝えている。 そして「入ってきなさい」という言葉をもって「話し合い」場面 は「終結」したが、同時にそれは行動（家に入る）でも示された。 その後のスタッフによる声かけは「日常生活」場面のそれであり、 声のトーンや速度が明らかに切り替えられた。「話し合い」が行われ た玄関は壁に囲まれた閉鎖的な空間であり、スタッフは「話し合い」 に集中し難いなおとに対し、他の子どもから隔離した場面を仮設した と見ることができる。話し合い」が終わるとなおとは室内に入るこ とを許されたが、これは生活する集団の境界と害際の空間の境界が同 一一であることを上手く用いた一例といえる。

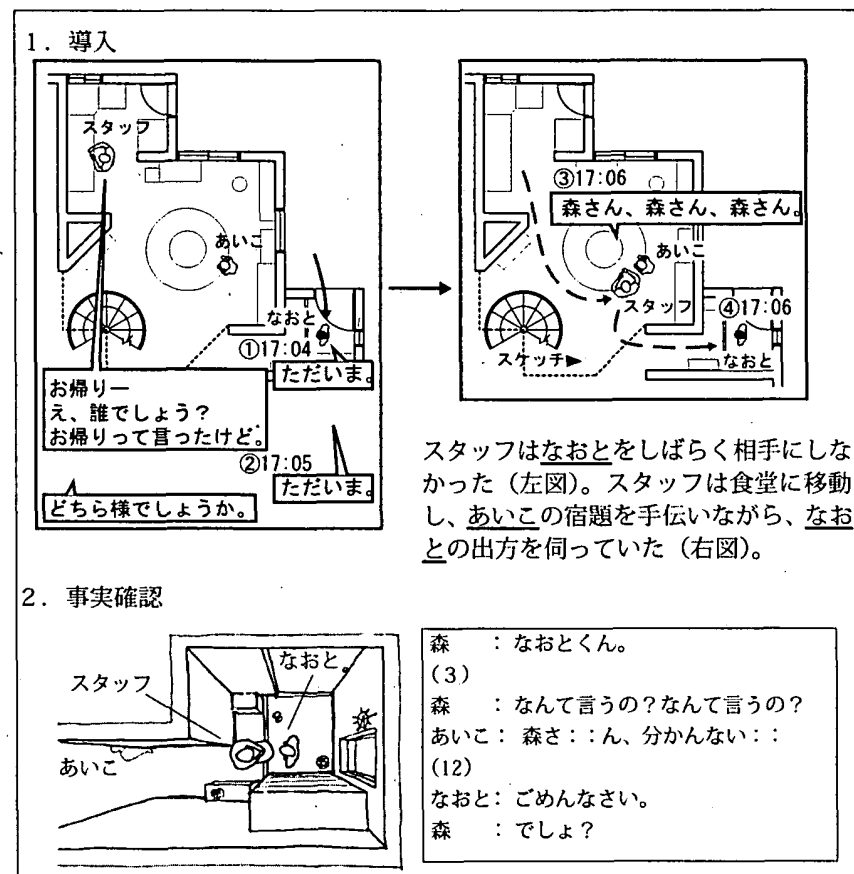

\section{5-3 言語化を通した事実認識}

図7の事奉確認におけるなおとの「ごめんなさい」という言葉から、 なおとは自分が問題行動をとったことは認識していると分かる。しか し、子どもが事実を䛊認している場合は事実確認が丁寧に行われる。 次はなおととあいこが喧嘩をした後の話し合いである。

17:15 10/15/2002. Tue

1 森 みんな偹ってきたんだよね、外から一緒にね：：上うこちゃんと、西いこちゃ んと、势おちんで州ってきたんだよね：：㛿ってきたらなにするの：って

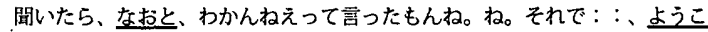
略]：ちゃんはって言ったらようこちゃんは分かったって言って行ったんだよね。

2㷊：その後でしょ?はい、その後どうなったの。

3なおと：なんか、㤎こちゃんがえらくないよって俺に言った。

4森： 恶いこちゃんがえらくないよって俺に言ったの?あなた言ったの?

5あいこ：言ってない。

6なおと：＝尋ったよ。

(6)

7 森：じゃあ、もし言ったとしよう。そして、それでどうなったの?

これらの会話からはスタッフが子ども達の行動を言語化し（1）、 子どもにそれを受け継がせている様が明らかとなった。辻褄が合わ なくなった時点で話は最初からやり直される。つまり「話し合い」場 面に招いて子どもは、スタッフが示す行動の言語化を模倣しつつも 言語化による事実認識のやり方を身につけていく。この方法では子 どもに関してスタッフが把握や推測できる事実が多いほど「話し合 いが行いやすく、その効果はますます上がると考えられる。スタッ フの滞在の中心となる台所・食堂から見通しが利く室内構成やコテー ジのスケールがそれをサポートしているように思える。

\section{6. 適応過程にみる新しい行動パタンの確立}

情短施設は短期入所の治療施設であり、Kホーム自身も通常子ども の治療目標を3ケ月ごとに計 2 年間で組み立てている。スタッフは子 ぞもの特性に応じつつそうした治療目標を意識して日常の働きかけを 行っており、実際子どもの行動の変化は3ヶ月程度のスパンで発見可 能なものが多い。それらの変化は主に子ども達が家庭及び社会生活を 送る上でプラスの能力の獲得 (ここでは適応船23) と呼ぶ) に向けられ ている。ここでは、それら適応過程の中でも重要な新しい行動パタン

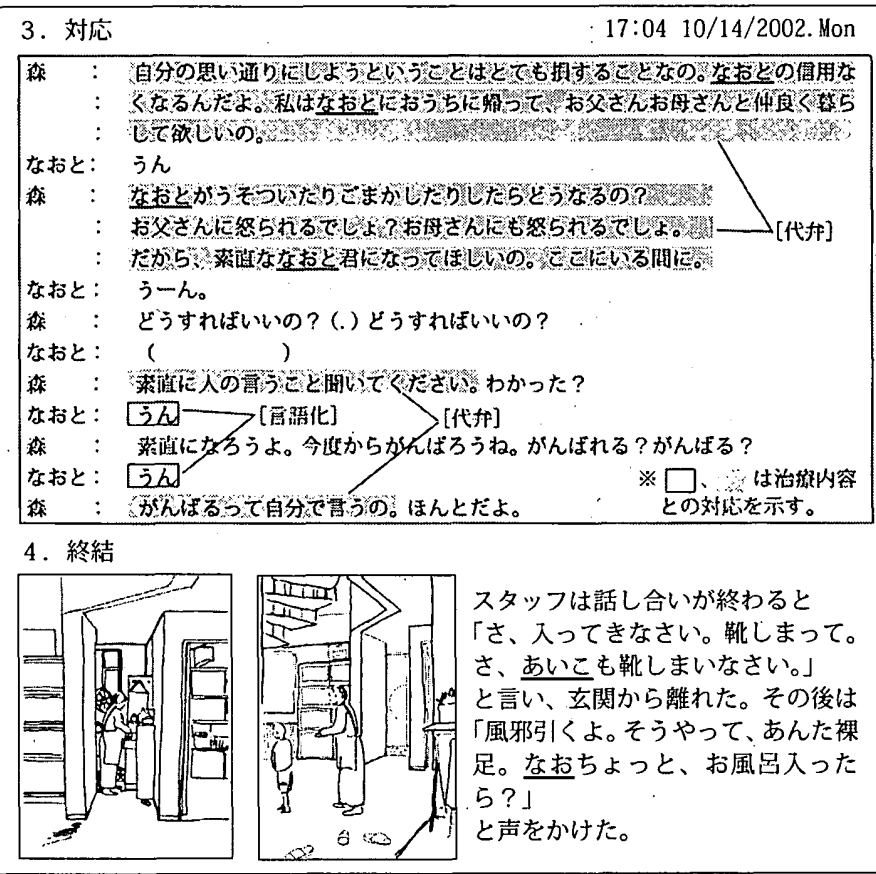

图 7.「話し合い」場面における環境療法の展開事例 


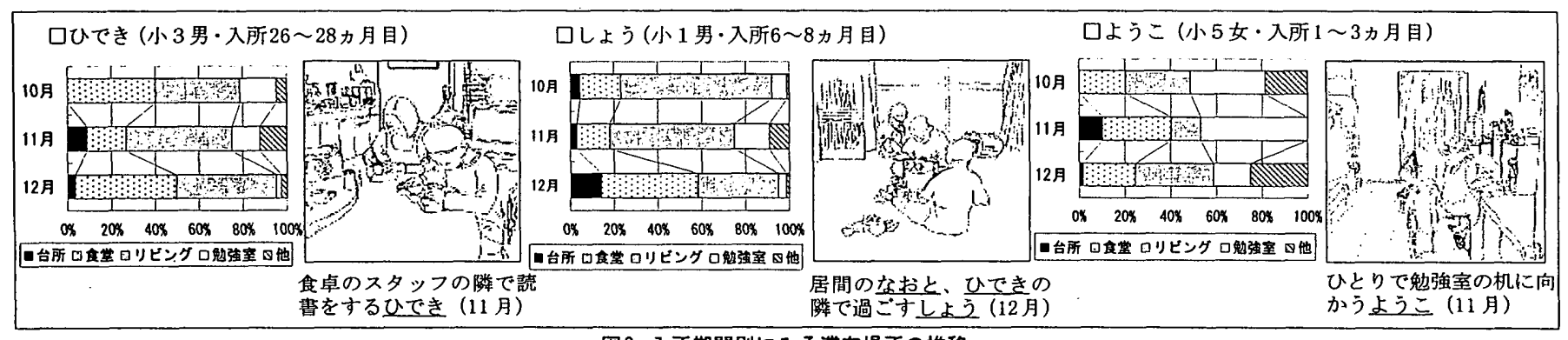

図8. 入所期間別にみる滞在場所の推移

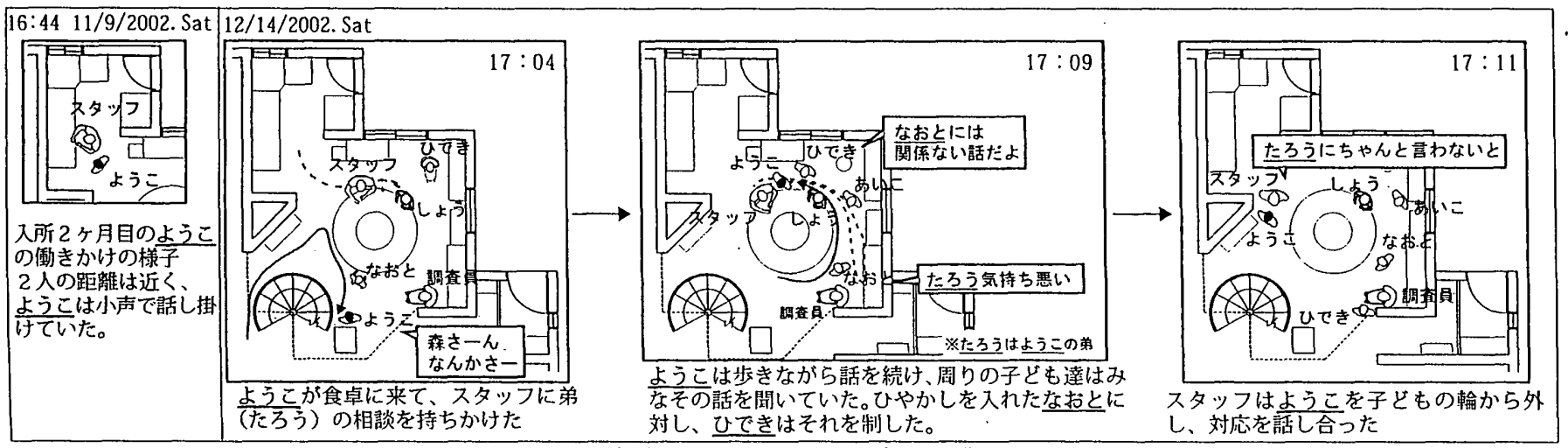

図9. 相談行為にみる新しい行動パタンの獲得

確立のケースを空間面 (拠点となる居場所の獲得) と人間関係面 (集 団との関係構築) の両面から取り上げる。

\section{6 - 1 . 滞在場所の推移}

入所 2 年後、半年後、直後の 3 人の子どもに対し、滞在場所の推移 を示す (図8)。ひできのように2年を越えた長期入所の子どもは、勉 強室から持ち出した本やおもちゃを使って食堂やリビングで過ごす傾 向にあった。5月入所のしょうは、勉強室滞在時間が短いことに変化 はなかったが、入所8ヶ月目（12月）には手伝いを通じてスタッフの 近くに居場所を求めるようになった (図 4参照)。一方、入所直後 (10 月)の上うこは、同年代の正いこやりかに比べ勉強室の滞在率が高い 傾向にあったものの (図3参照)、居場所がなくうろうろしたり他の 子どもの喧嘩に首をつっこんでいた。勉強室で1人で過ごすことが更 に増えた2ヶ月目（11月）を経て、3ケ月目（12月）には滞在場所が リビングへと広がっており、西いこやりかなど長期入所者の行動パタ ンに近づいていると考えられる。

\section{$6-2$. 集団との関係構築}

ようこの適応は滞在場所と同じくスタッフへの働きかけにも表れ た。入所1、2ケ月目の㗢きかけはスタッフのすぐ隣で小声で1分程度 の短い話しかけが主であったが、3ケ月目にはスタッフに悩みを相談 する（図9）という変化を見せた。弟と一緒に入所し、面倒見の良い 姉として振る舞っていた彼女が弟に対する悩みをうち明けたが、2人 の距離は3メートル程あり、ようこは食堂中に聞こえる大きな声で話 し掛けている。「悩みごとを打ち明けるには集団に安心感があるから 肚17)」であり、彼女がスタッフや周りの子どもに気を許すようになつ たと考えられる゙20)。これは彼女が3ケ月の生活で食堂における他の 子どもの「話し合い」や相談の行為を見る中で、ここでは悩みを相談 しても良いことを学び実行した（新しい行動パタン），一例とも言え る。またこの時、すできはようこをからかったなおとを注意した。一 人っ子であるひできは2年前の入所時には子ども同士の付き合いをほ とんど築けずにいたようだが時17)、Kホームでの生活を通じて生活集
団の維持に関与するまでに成長している。

7. まとめ

ケーススタディを通じて明らかになった情緒障害児療育に必要とさ れる与件について述べてきたが、以下にそのポイントを再揭する。 (1)日常生活と一体化しているため従来ブラックボックスとなっていた 環境療法であるが、その実際は安定した「日常生活」場面とその中に 埋め込まれる「話し合い場面の2つの層から構成されており、雨者は 密接に連関している（図 2)。(2)療育の基盤となる「日常生活」場面 は、生活拠点としてのLDKを中心とした日々の活動を通じて生成が絽 り返されるダイナミックなものであった。舎のメンバーの多くが関 与するそこでの働きかけとフィードバックによって人間関係が逐次構 築されていくが、その際に空間も様々な形で活用されていた（図 4、 5)。(3)「話し合い」は問題行動が明らかになった時点で逐次行われて おり、具体的には「導入」「事実確認」対応」「終結」の 4 過程を有するこ とが多い。またその際にスタッフは、そのありようは様々ではある が、一定期間安定した「話し合いが持続できるよう階段や壁などの 空間要素を意識していることも分かった(図7)。(4)このように日々の 生活を繰り返しながら子ども達の間で社会性の高い行動パタンが徐々 に形成されていくのが環境療法の実際である。具体的には、滞在場所 と集団における関係構築の両者が相補的に変化する中で、新しい行動 パタンが形成されていくようである（図8、9）。(5)観察により抽出さ れた行為の多くは、生活集団内での自己の位置付けを巡るものであっ たが、その軸となっているのはメンバーが見ている中でのスタッフと の関係の構築であった。今回調查対象とした施設では、生活拠点であ るLDKは同時に各メンバーのコミュニケーションが集中する場でもあ り、「話し合い」の格好の契機が逐次提供されていた。スタッフがコ ントロール可能な程度にその密度が限定されている(集団が少人数で ある)、空間の活用性が高い（見通せる+利用可能な空間要素多 (螺 旋階段・玄関アルコーブ・キッチンアルコーブ・大きな円テーブル等） 
といった小舎型空間の特色がこうした状況に寄与していることは十分 に推察可能であろうと思われる。

謝辞 調查に御協力頂いたKホームの園長先生をはじめとする関係者の皆様、環境療法 等について御助言頂いた、東北大学学生相談室カウンセラーの吉武清美先生に哚く感謝 申し上げます。

なお、本文中に登場した人物の名前すべては仮名としました。

註

1）対象となる児童は、家庭、学校、近隣での人間関係のゆがみによって情緒生活に障 羖をきたし適応が困難になった児童であり、知的あるいは身体的欠俩や器質的疾患が原 因となって2次的に問題行動を示す児童、さらには小児分裂病や神経症のような医撩機 関が报う疾患を有する児童は除外される。

2） 2000 年の「健やか親子 21 検娮会」報告書（厚生省）に上り、21 世紀当初の 10 年間 に子ども䘕政が目指す目標值として、すべての都道府県に1ケ所ずつの情短施設を設置す ることが明示された。

3）面接の棈造とは時間、期間、場所や費用などが決められているということ、つまり 一般的に約束事、禁止事項などに関しての両者の契約といえる文13)。

4) 環境㙩法 [milieu therapy] とは人格的不適応の問題が環境の条件に基づいていると 考えられ、これを調整することによって正常な生活を取り戻そうとするもの(誠信心理 学事典」より)であり、Aichhorn、Redl、Bet telheimらによりアメリカを中心に発展して きたものである。環境療法において特に非行や行動障害を持った児童を対象とした場合、 その土台にはRedl, Fritzの「生活場面面接（life space interview)」の考え方がある。その 焦点としては「1.生活上のできごとの治療的な活用(clinical exploitat ion of life event)」、 「2.クライエントが何か問題を起こしたときの、その場での即座の情緒的な介入 (emotional first aid and on the spot)」の2点が举げられる汭。なお、一部の情短 施設においては環境療法を前述の生活場面面接、または生活場面治療と呼ぶ。

5)「小舎」とは「眠る、食べる、㽤らんする等の、日々の基本的な生活行為が主として 行われる生活空間か、、小集团でおおよそ 10 人前後以下の単位で、空間的にも分㒕された 形で計画された場合。とくに食べる行為の集厈単位が目安となる。、「中舎」とは「前記 の単位がおおよそ24-5人前後以下の単位の場合」、大舎」とは「上記の単位がおおよそ 24-5人前後以上の場合」を言う文14)。

6）Kホームは当初、同法人が敷地内に運営する児童養護施設の集团不適応児に対する 処遇小舎として 1971 (炤和 46) 年に最初の 2 棟が開設された。その後 5 棟にまで增設さ れ、1979（同 54）年に全国で11 番目、民間としては最初の情短施設として認可された。 故に、小舎型施設についての考察は情短施設のみならず、広く児童竟謢施設の課題にも なりうると考えられる。

7）情短施設の職員規定として「情短施設には、医師、心理潦法を担当する職員、児童 指導員、保目、看掼沀、栄養士及び調理員を圆かなければならない。」(児童福祉法第九 音の五) とある。本来、入所児が 35 名の場合スタッフの最低数は 14 名となるが、Kホー ムでは現在それを上回る 18 名のスタッフ（入所児 50 名の体制）が働いている。

8）参考文献 15、16、および吉武清実氏へのヒアリングを元に図 2 を作成した。

9）西澤文5) は、環境療法においてまず必要なのは、子どもの「安全感・安心感の再形 成」と「保護されているという感覚の再形成」であるとした。次いで、新しい行動パタ ンを確立する過程には、スタッフや他の子どもとの生活を通じて「人間関係の修正」感 情コントロールの修正」「自己イメージ、他者イメージの修正」「問題行動の理解と修 正」が図られることが必要であるとした。

10．情短施設はおおむね 2 年を退所目標としており、Kホーム入所児童の平均在所期間 は 2 年 3 ケである。また退所者のうち $46.6 \%$ は在所期間が 2 年以内（平成 4 〜 13 年度 の平均)であった（2002年10月現在)。

11) エスノメソドロジー [ethnomethodology] とはアメリカ社会学の中でGarfinkel, H. が創設した、「普通の人々は (ethno）日常生活の対人関係における意志踈通行為の基盤 をどのようにして組み立て意味づけしているのかというそのやり方 (method) について の経験的な研究 (logy)」であり、「常に個別的具体的な場所で日常のわれわれの四われ ているく压倒的なちから>がはたらくさまに出会い、それを記述し相対化しょうとする 実践」である。文17.187

12）会話の記述に使われた記号の意味は次のとおりである。「?」語尾の音が上がって いること、「：：」直前のことばが不完全なまま途切れていること、「／」言菄の重なり、 「=」途切れなくことばもしくは発話がつながっていること、「( )」なにかことばが発 せられているが、間き取り不可能であること、「(数字)」その数字の秒数だけ沈黙のあ ることを示す。また、ごく短い間合いは「(.)」という記号で示される文19)。

13）「表出」とは内的心理的過程が知られうる身体的現象の総体と定義される。一般的 には、顔の表悄や全身的運動や音声のような表出運動をさすが、広義には心理的特徵を 示すとされる人相や体格のような形態的特徵や、書き物、絵画や堭楽などの芸術作品の ような静的客観的な物まで含められる場合もあり、一定していない义20)。

14）「代弁」とは本人に代わって意見を述べること（「大辞林 第二版」より）である。 吉武义21) は大人が子どもの気持ちを代弁することで子どもの状沙理解を助け、また行動 のモデルにつながるとしている。

15）調查期間は 2002 年 10月 9-15日、11月 2-6、9-10日、12月 9-15日である。調查時 間を 16 時半から 17 時半の 1 時間とした理由は、Kホームでは、食事時間、就寝時間、17 時の門限（学校活動や認められた活動（バイトなど）は除く）の規則のみで、基本的に は子どもが主体的に生活を送っており、1日の中で、この時間帯は『1.子どもの自由
時間であり、活動場所が 17 時までは自由、17時以降コテージ内で自由と変化する。2. スタッフは夕食の支度などに䎲しく、子どもから㗢きかけないと関わってもらえないた め、子どもの自主的な動きが見られる。3．夕食へ向けて精神的にも物理的にも準備の 時間である』ことより、Kホームの生活像が凝縮された時問であると考えたからである。 よって、今回の調查ではその対象は小学生が中心となった。

16）本稿では入所呪の家族については扱わなかった。情緒障害児の回復に家㵀の果たす 役割も重要ではあるが、プライベート性の高い問題であること等を考盧し、今回はまず 入所児の生活を扱うこととしたためである。

17）生活参与調查期問に加えて、2002 年 7 月 16,17 日、8 月 $5,7,14,15,28$ 日、10月 4 日、11月14,22日、12月16日、2003年1月29日にスタッフへのヒアリング調査を行っ た。ヒアリングでは主にスタッフの行動の意図や療法上の意義、各々の子どもの特徴や 彼らのKホームでの生活を通じての変化などを聴取した。

18）註15に記した調查時間の総計（連絖する 3 ケ月の各 1 週間)における子ども及びスタッ フの衍為についてその㴖在場所を把握し、1日あたりの平均値を算出し、その構成比を示し た。尚、「他」は「入浴、洗面、手洗い、布団敷き、洗濯物の取り込み」を含む。

19）中高生は帰宅後夕食までは時問が短い為、夕食の後や小学生が梫る20時以降、消 灯の 21 時以前に主に食堂でスタッフに働きかけを行っていたことが観祭されている。 20)スタッフへの働きかけは各人により頻度・方法を異にするが、「話しかけ」と「ス タッフの活動への参加」の二種類に分類できる。話しかける話題としては、入所間もな い子は学校や遊びを通じての一日の出来事に関するものが多く徐々に自分自信や家族の 話、入所までの経験および将来への展望、また悩みの相談などが增えてゆくことが調査 およびヒアリングは17)で確認された。

21）「話し合い」は子どもの問題行動に対して即座になされるものである。スタッフの 声のトーンや会話の内容、子どもの距軅の取り方や他の子どもに対する態度などにおい て「日常生活」とは明確に区別していることが観察された。「話し合い」は午後、夜に 行われることが多く、一日につき平均 1 ～2 場面程度観祭できた。代衣的な話し合い頻 度の例を以下に示す。

$[12 / 15 / 2002$. Sun]

\begin{tabular}{|c|c|c|c|c|c|}
\hline $16: 00$ & 17:00 & 18:00 & 19:00 & $20: 00$ & $21: 00$ \\
\hline あいこ & の話し & あし & 合い/30分 & 学生就實 & 中高生就归 \\
\hline
\end{tabular}

22）「対応」とは代弁措14) を通じて問題行動の背景に理解を示した上でそれに代わる行 動を教えること济22) である。

23）「適応」とは、意図的に環境（状況）に応ずる行動を学習するとともに自己に適合 するように環境に変化（変革）を加えたり、状況（場面）を作り出したりする行動を言 う文23)。

\section{参考文献}

文 1 ) 昭和 37 年度厚生白啛

文2）『心をはぐくむ3一総合環境療法の臨床』全国情緒障害児短期治療施設協議会、2002 文3）岩田康子：児童虚待、臨床精神医学、24(8)、1053-1059、1995

文 4) 大迫秀樹:䖒待を背景にもつ非行小学生に対する治療教育一教謢院における環境㙩法 アプローチ、心理臨床学咞究、17(3)、249-260、1999

文5）西澤哲『トラウマの臨床心理学』金删出版、1999

文6)安田勉『治療的環境の形成と生活場面面接』心理治療と治療教育一情緒障害児短期治 療施設研究紀要第 7 号、情緒障害児短期治療施設協訮会、1996

文 7 ) 浅倉恵一、峰島厚編著『子どもの権利条約」時代の児童福祉 2 子どもの福祉と施設 養菠』ミネルヴァ書房、2000

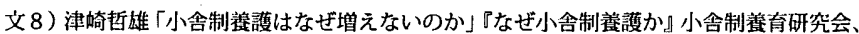
1999

文 9) 小野田泰明, 营野實, 針生承一, 本間敏行, 大林政夫, 濑戸信太郎: 養護施設のリニュー アルにおける建築計画的実践、日本建築学会技術報告集 第3 号、P. 212、1996

文 10）小野田泰明、瀨戸信太郎ら：建て替え前後における生活条件の変化 養護施設のリ ニューアルにおける建築計画学的実践 その $3 \cdot 4$ 、日本建築学会大会学術講演梗概集 E-1 分冊, pp. 47-50、1997

文11）佐藤郁哉『フィールドワークの技法 問いを育てる、仮説をきたえる』新曜社、2002 文12) 久保紘章: 構造化されていない面接一生活場面面接の視点からーソーシャルワーク研 究、Vol. 16 No.4、1991

文 13）小松敬：「生活場面面接」研究の構造と課題-『ソーシャルワーク研究』通卷 95 号に おける特集「生活場面面接」をめর゙ってー、ソーシャルワーク研究、Vol. 26 №.3(103)、2000 文14）筧和夫、萩㽠秋雄、吉田あこ、加藤隆『新建築学大系32 福社施設・レクリエーショ ン施設の設計」 彰国社、1987

文15）高橋重宏・庄司順一編著『福祉キーワードシリーズ 子ども虐待』中央法規、2002

文16) 平木典子、袈岩秀章『カウンセリングの技法』北樹出版、2001

文17) 下中邦彦編『新版 心理学事典』平凡社、1981

文 18）山田富秋、好株裕明編『エスノメソドロジーの想像力』せりか書房、1998

文 19）好杜裕明、山田䉰秋、西阪们編『会話分析への招待』世界思想社、1999

文20）K・ライター著、高山臭知子訳『エスノメソドロジーとは何か』新嚯社、1987

文21)吉武清实:自由保㕕アプローチと設定アプローチー障害児教育における個別化のため のモデルー 日本障害坚教育実践学会就第 4 巻第 1 号, pp. 72-76、1997

文 22) Albert E. Trieschman, James K. Whittaker, Larry K. Brendtro: The other 23 Hours. Chicago : Aldine Pub. Co, 1962 (西澤哲訳『生活の中の治療 子どもと暮らす チャイルドケアワーカーのために』中央法規、1992)

文23）三宅和夫、北尾倫彦、小嶋秀夫編『教育心理学小辞典』有斐閣、1991 